\title{
Accessing land cover change in Bo Trach district, Quang Binh province based on high- resolution satellite imagery based on object- oriented perspective
}

\author{
Đánh giá biến động lớp phủ mặt đất tại huyện Bố Trạch, tỉnh Quảng Bình bằng \\ ảnh viễn thám độ phân giải cao theo phuơng pháp định huớng đối tuợng
}

Research article

Pham Quoc Trung ${ }^{1}$, Nguyen Hoang Khanh Linh ${ }^{2}$, Huynh Van Chuong ${ }^{3}$, Truong Thi Huong Dung ${ }^{1}$

${ }^{I}$ Department of Natural Resources and Environment, Quang Binh Province; ${ }^{2}$ Faculty of Land Resources and Agricultural Environment, Hue University of Agriculture and Forestry, Hue University, 102 Phung Hung, Hue City, Vietnam;

${ }^{3}$ Hue University, 06 Le Loi Street, Hue City, Vietnam

\begin{abstract}
This paper aims to assess land cover change by high-resolution remote satellite images in Bo Trach district, Quang Binh province. The study used eCognition Developer 9.1 to classify SPOT and Sentinal-2 images of the study area. Objects on the images are characterized by values of Channels, including Red, Green, Blue, NIR, Brightness, NDVI, and RIV. Since then, maps of land cover status in the year of 2005, 2010, and 2017 were created with high accuracy $92.22 \%, 91.28 \%$, $94.22 \%$, respectively. Overlaid three land cover maps to develop the land cover change maps of two periods 2005-2010 (period 1) and 2010-2017 (period 2). The results show that there is a variation in the area of land cover types, especially agriculture and forest land. Of which, agrarian land increased by $7.7 \%$ in period 1 and $9.95 \%$ in period 2 . Whereas, forest land decreased by $0.6 \%$ in period 1 and $1.5 \%$ in period 2 .
\end{abstract}

\begin{abstract}
Bài báo này nhằm muc đích đánh giá biến động sử dụng đất bằng viên thám độ phân giải cao tại huyện Bố Trạch, tỉnh Quảng Bình. Nghiên cúu sử dụng phần mềm eCognition Developer 9.1để phân loại ảnh ảnh SPOT và Sentinal-2 trên địa bàn nghiên cứu. Các đặc trung của đối tương trên ảnh được xác định dụa trên giá trị độ sáng các Kênh 1, Kênh 2, Kênh 3, Kênh 4, giá trị độ sáng trung bình (Brightness), chi số khác biệt thực vật (NDVI) và tỷ số thục vật (RIV). Tù đó xây dưng được các bản đồ lớp phủ mặt đất các năm 2005, 2010, 2017 với độ chính xác lần luợt là 92,22\%, 91,28\%, 94.22\%. Chồng ghép các bản đồ lớp phủ mặt đất, xây dụng bản đồ biến động sủ dụng đất giữa hai thời kỳ 2005-2010 và 2010-2017. Kết quả nghiên cứu cho thấy có sụ thay đổi giữa các loại hình lớp phủ gồm: đất nông nghiệp tăng khoảng 7,7\% giai đoạn 1 và 9,95\% giai đoạn 2. Đất lâm nghiệp giảm khoảng 0,6\% giai đoạn 1 và 1,5\% giai đoạn 2 .
\end{abstract}

Keywords: high resolution, land cover change, object-oriented classification, satellite image

\section{Introduction}

The rapid development of remote sensing technology has brought many practical applications in many different fields, including agriculture. This issue has also been introduced by the Vietnamese Ministry of Agriculture and Rural Development (MARD) in its professional requirements for inventory in the period 2012-2015 under Deci- sion No. 3183 / QD-BNN-TCLN on December 21, 2012 (MARD, 2012). Under the guidance of this decision, land classification is based on high-resolution remote sensing images with the supports of eCognition image interpretation software (MARD, 2012). Importantly, up to now, there has not been a standard guide for using eCognition to interpret and create the land cover map from highresolution satellite images. 
On the other hand, current image interpretation techniques are based on pixel-classification, which is performed on software such as ENVI, ERDAS, etc. Despite this interpretation technique is easy to implement and gives fast results, it depends too much on the experience of the image interpreters, having not high accuracy. Objectoriented classification method with the support of eCognition Developer software is considered as a positive new approach to overcome this disadvantage. In which, multi algorithms are created to characterize entirely objects, which achieve higher accuracy than the pixelclassification method. Therefore, it requires a specific process for the user, especially local managers to use the tool in their day-to-day work and to improve efficiency and quality of work.

Studies were carried out in Bo Trach district which is located at the north gate of Dong Hoi city, at latitude from $17^{\circ} 14^{\prime} 39^{\prime \prime}$ to $17^{\circ} 43^{\prime} 48^{\prime \prime}$ and longitude from $105^{\circ} 58^{\prime} 3^{\prime \prime}$ to $106^{\circ} 35^{\prime} 573^{\prime \prime}$, occupying the whole horizontal of Vietnam. With such a special geographic location, Bo Trach borders both the East Sea and the Laos frontier and covers an area of 2,124 square kilometers. It has an important National Park, namely Phong Nha-Ke Bang, recognized as the natural heritage of the world by UNESCO's World Heritage Sites two times for its geological values in the year 2003 and the world's largest cave in the year 2015. Bo Trach district has a vital role in the socio-economic development of Quang Binh province. In recent years, the area of land cover types within the region has been continuously changing. Therefore, updating and correcting information on land changes are very necessary. Accordingly, the previous study of Trung et al. (2018) already applied remote satellite image for accessing the change of land cover within Bo Trach district. However, the interpreting accuracy of the medium resolution was not high. Based on mentioned reasons, the study of high-resolution remote-sensing image interpretation using the objectoriented method for mapping land cover is vital, especially local management in Bo Trach district, Quang Binh Province.

\section{Data and methodologies}

\subsection{Data}

In this study, it requires two scenes of SPOT 5 with $10 \mathrm{~m}$ resolution, covering the area of Bo Trach district for the year 2005 and 2010. However, it needs only one scene of Sentinal-2 with $10 \mathrm{~m}$ resolution acquired in the year 2017 to extract the image as the boundary of Bo Trach district. All the images have good quality with the percentage of cloud under $10 \%$. SPOT5 images were purchased from Department of Vietnamese National Remote Sensing. Whereas, the Sentinal-2 images were downloaded free from https://scihub.copernicus.eu.

\subsection{Surveying data}

Sampling data for image interpretation and evaluation of interpretation accuracy was applied in this study. The type and scale of samples were selected cross through all territory within Bo Trach district, by using observation meth- ods, interviewing experts. The location of collected samples was identified by the Map 76CSX device. The sample size is 450 samples, of which 50 samples are water, 200 samples are forest land, 66 samples are built-up land, 84 samples are agricultural land, and 50 samples are sandy land (Table 2).

Sampling data for image 2017 was collected on the field. Whereas, sampling data of images in the year 2005 and 2010 were obtained from reference maps. In this study, reference maps were collected from Bo Trach Department of Natural resources and Environment, including land use map, topographic map in relevant years.

\section{Table 1. Detailed information of satellite images}

\begin{tabular}{|c|c|c|}
\hline Year & & Image information \\
\hline \multirow{5}{*}{2005} & Name & $\begin{array}{l}\text { Scene } 1: 272-315 \_04012006 \\
\text { Scene } 2: 273-315 \_26012005\end{array}$ \\
\hline & Date & $\begin{array}{l}\text { Scene 1: 04/01/2005 } \\
\text { Scene } 2 \cdot 26 / 01 / 2005\end{array}$ \\
\hline & $\begin{array}{l}\text { Cloud } \\
\text { percentage }\end{array}$ & $9.8 \%$ \\
\hline & Satellite & SPOT5 \\
\hline & Resolution & $10 \mathrm{~m} \times 10 \mathrm{~m}$ \\
\hline \multirow{5}{*}{2010} & Name & $\begin{array}{l}\text { Scene 1: 272-315_12032010 } \\
\text { Scene 2: 273-315_24022012 }\end{array}$ \\
\hline & Date & $\begin{array}{l}\text { Scene 1: } 12 / 03 / 2010 \\
\text { Scene 2: } 24 / 02 / 2010\end{array}$ \\
\hline & $\begin{array}{l}\text { Cloud } \\
\text { percentage }\end{array}$ & $4,7 \%$ \\
\hline & Satellite & SPOT5 \\
\hline & Resolution & $10 \mathrm{mx} 10 \mathrm{~m}$ \\
\hline \multirow{5}{*}{2017} & Name & $\begin{array}{l}\text { S2A_MSIL1C_20170220T0317 } \\
\text { 41_N0204_R118_- } \\
\text { T48QXE_20170220T032708 }\end{array}$ \\
\hline & Date & $20 / 02 / 2017$ \\
\hline & $\begin{array}{l}\text { Cloud } \\
\text { percentage }\end{array}$ & $1.7 \%$ \\
\hline & Satellite & Sentinel 2 \\
\hline & Resolution & $10 \times 10 \mathrm{~m}$ \\
\hline
\end{tabular}

Table 2. Collected samples for interpretation

\begin{tabular}{|l|l|l|}
\hline Sample & On the image & On the field \\
\hline 1. Water & & \\
\hline & & \\
\hline
\end{tabular}




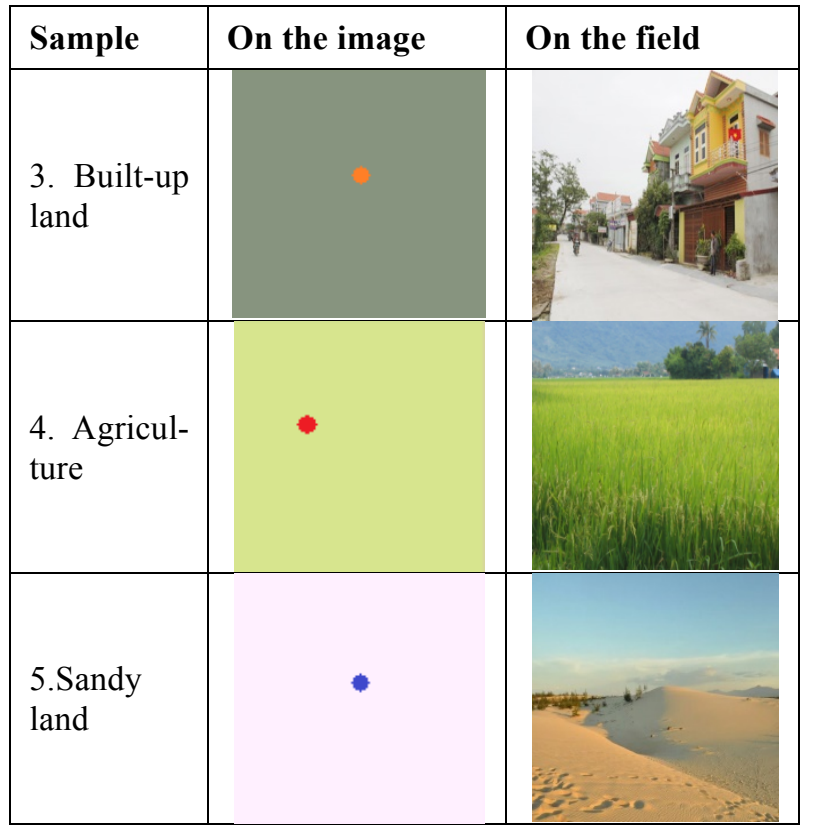

\subsection{Interpretation image}

To interpret satellite images with eCognition software, it requires identifying the threshold for each class. Therefore, it is critical to calculate the brightness values of each spectrum channel. In this study, four channels were utilized, including Red, Green, Blue, and Near Infrared. Besides, additional categories were used to classify the image include Brightness, NDVI (Normalized Difference Vegetation Index) and RIV (Ratio Vegetation Index).

Brightness $=($ Channel $1+$ Channel $2+\ldots+$ Channel $n) / n$ $\mathrm{NDVI}=(\mathrm{NIR}-\mathrm{Red}) /(\mathrm{NIR}+\mathrm{Red})$

$\mathrm{RIV}=\mathrm{NIR} / \mathrm{Red}$

In which: NIR is the radiation value of near infrared, Red is the radiation value of the visible wavelength.

From the statistics of image samples, mathematical methods were applied to find threshold values to classify of image objects (Figure 1).

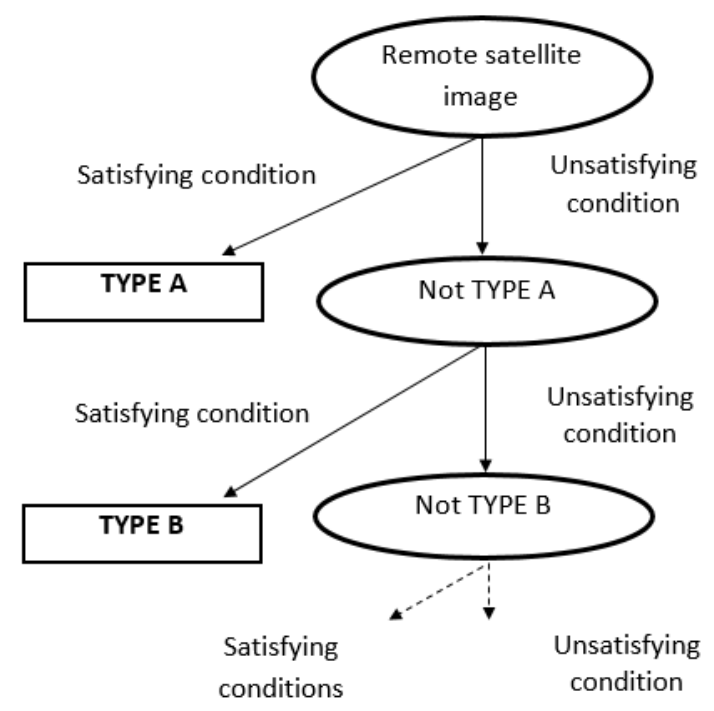

Figure 1. The classification algorithm
Based on the threshold classification, high-resolution remote satellite images were interpreted with the support of eCognition Developer 9.1 (Trimble, 2015) The image interpretation framework is summarized in Figure 2.

\section{Results and discussions}

\subsection{Image interpretation}

In this study, we tested various times and found the parameters which slice the image as suitable fragmentation for the study area. The parameters include the shape: 0.2 (color - color: 0.7); Compactness: 0.5 (smoothness: 0.4); Scale - Scale parameter: 30; Weight of 4 channels: Channel 1 (Blue): 1, Channel 2 (Green): 1, Channel 3 (Red): 1, Channel 4 (NIR): 1. The result of image fragmentation is shown in Figure 3. It shows that the fragmented objects within the image are relatively homogeneous, which is a critical condition to choose the above fragmentation parameters.

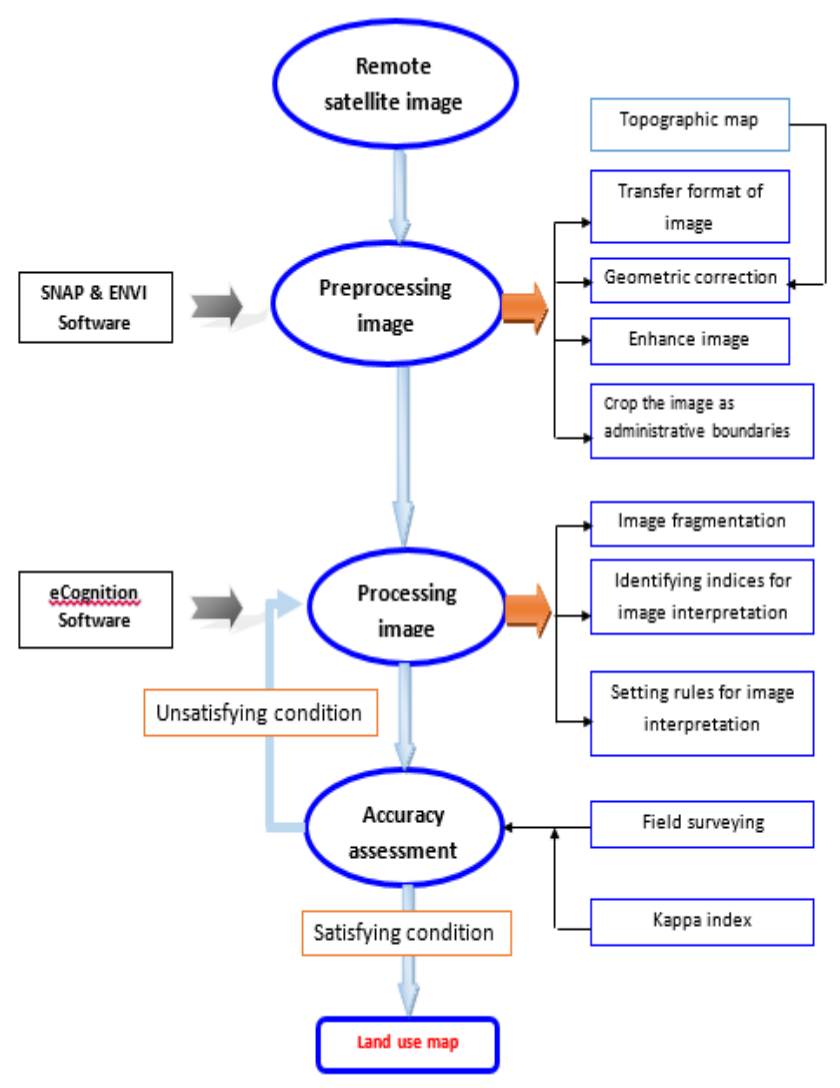

Figure 2. Image interpretation framework

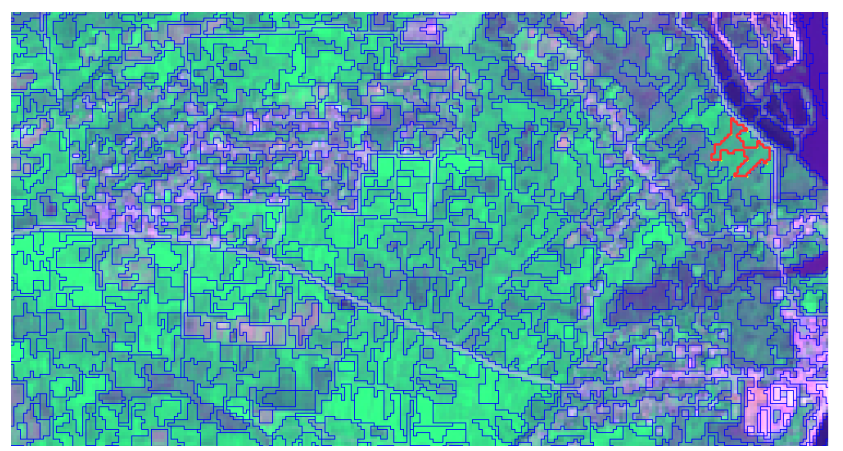

Figure 3. SPOT5 image fragmentation 
After fragmenting the image, it is necessary to create the image interpretation key. Firstly, it requires determining the number of classes within the image. And the next step is to name and assign the color to each layer. In this study, we conducted the classification as the following classes: Agri- cultural land, Built-up land, Forest, Sandy land, Water. The classification tree was built on the eCognition software as shown in Figure 4.

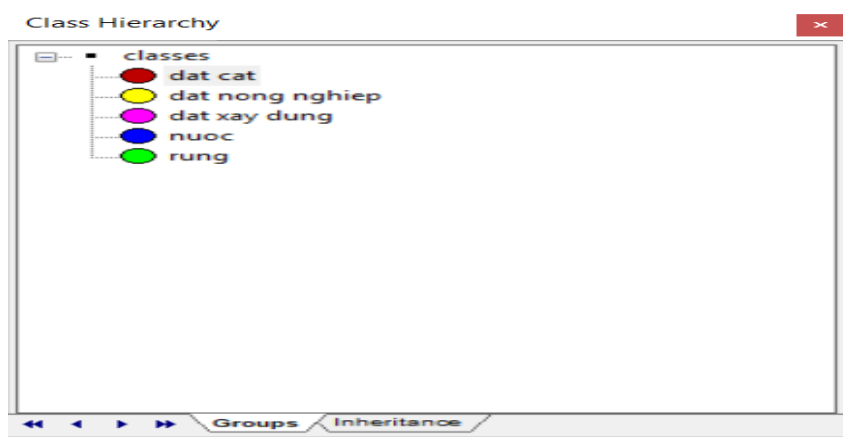

Figure 4. The class hierarchy of image classification

Each brightness value of the spectrum channels or the average brightness value of the image channels is a crucial criterion for classifying satellite image. To have high accuracy in interpreting model, it needs more rules which help to differentiate the complex objects. Previous studies have shown that the NDVI and RIV indices are used to determine the distribution of vegetation, assess the growth and development status of the crop. The distinction between the different vegetation layers is very high.

The NDVI and the RIV indices were established on the eCognition software (Figure 5).
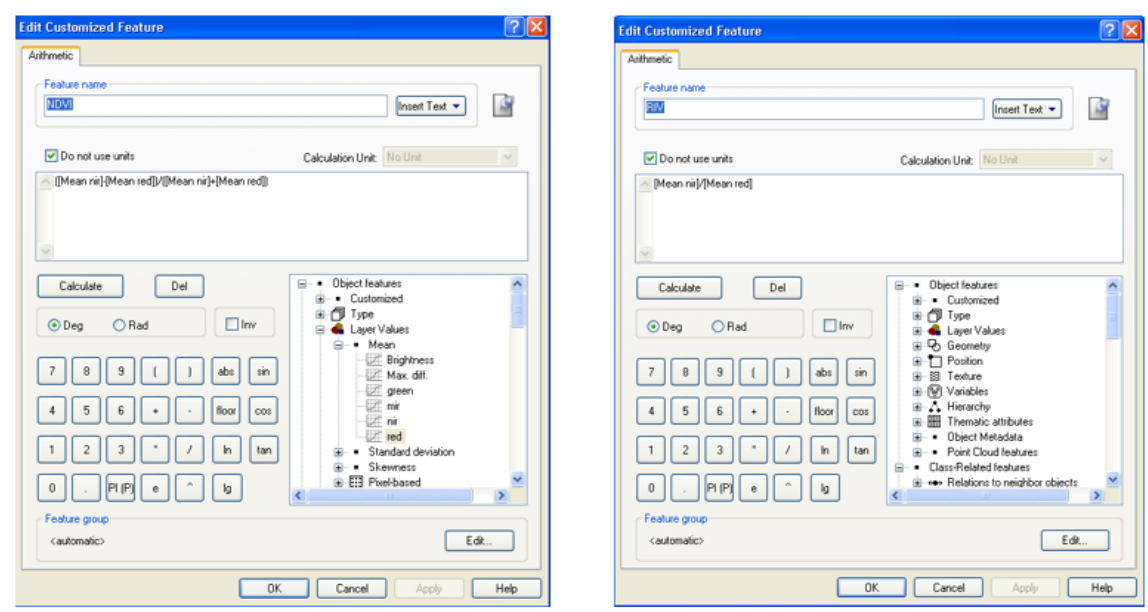

Figure 5. NDVI index and RIV index

As mentioned above, samples of five classes were collected, including 84 samples of agricultural land; 66 samples of built-up land; 50 samples of sandy land; 50 samples of water; 200 samples of forest. Based on values of the image channels (Red, Green, Blue, NIR), Brightness,

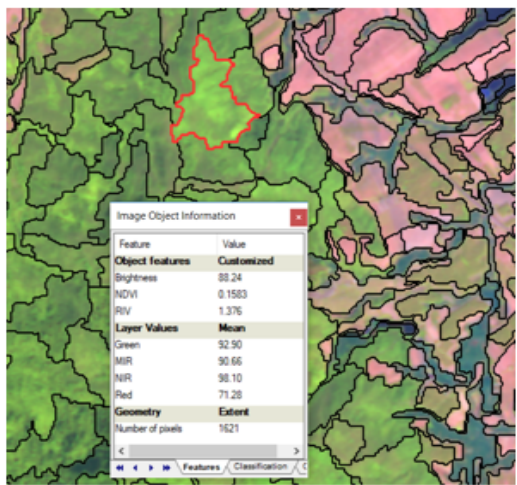

NDVI, and RIV index, the characteristic values of an image object are determined by the eCognition software. It means that each class within the image has its threshold of unique values (Figure 6).

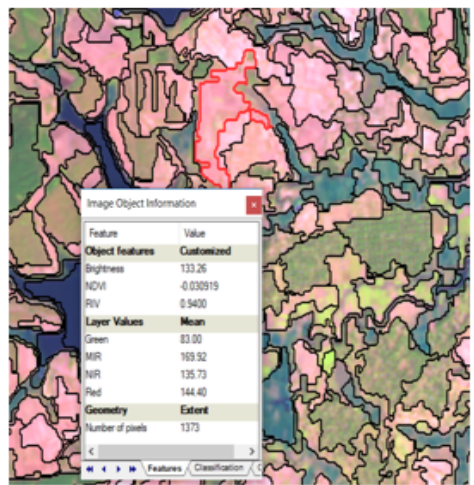

Figure 6. Characteristic values of two different objects 
Based on the threshold values that had been determined for each class, the image interpretation key was constructed as the following Figure 7.

As can be seen, forest land was identified with the value of NDVI $\geq 02$ and Mean NIR $\leq 88$. Objects not covered by the first condition were the remaining land cover types. The next step was continuing the selected criteria to classify land cover type further. Water was determined based on the threshold of NDVI $\geq 0.2$ and $88>$ Mean NIR $\leq$ 100 . Objects not covered by the second condition were the remaining land cover types. Sandy land was classified by Brightness values within the ranges from 190 to 220 . Objects not included by the third condition were the remaining land cover types. The built-up land was differenced by the range $100 \geq$ Brightness values $<190$. Objects not covered by the fourth condition were the agriculture land. Based on rule set values, land cover maps at Bo Trach district were automatically interpreted from satellite images for the year 2005, 2010 and 2017, respectively. It found that image was less divided into fragments with object classification approach, which could give good interpretation results. 450 surveying samples were conducted to evaluate the accuracy of the image interpretation results were conducted. These samples were independently collected from the used interpretation samples. The result showed that land cover map in the year of 2005, 2010, and 2017 was created with high accuracy with kappa index $92.22 \%, 91.28 \%, 94.22 \%$, respectively. Comparing with previous study by Trung et.al (2018), also accessing the change of land cover in Bo Trach district with Landsat satellite, it shows that the interpretation accuracy of medium resolution imagery by pixel classification approach has kappa index under $90 \%$. As can be seen, the object classification approach could give higher interpreting classification than pixel classification approach.

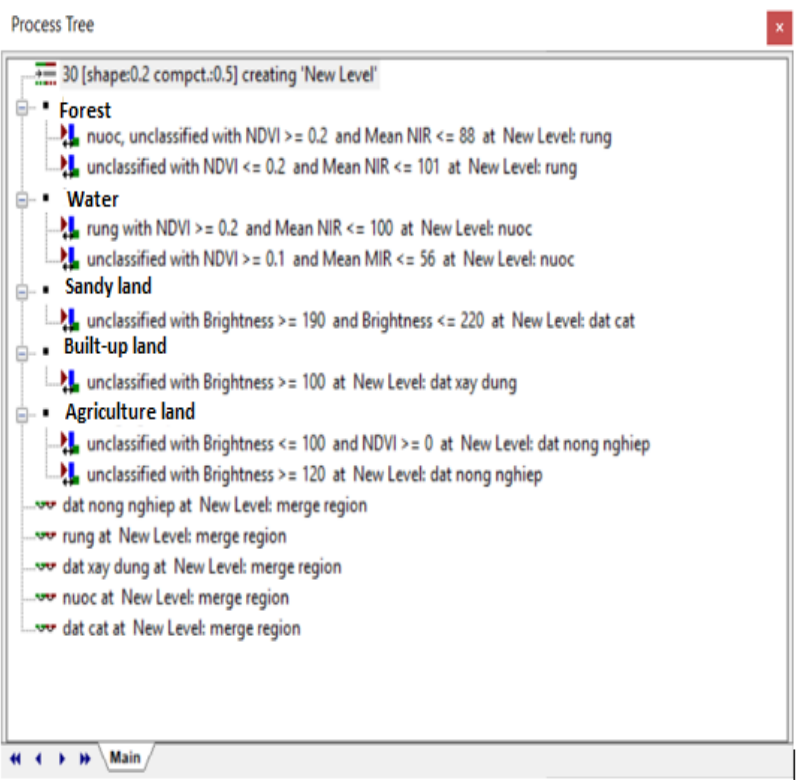

Figure 7. Image interpretation key set
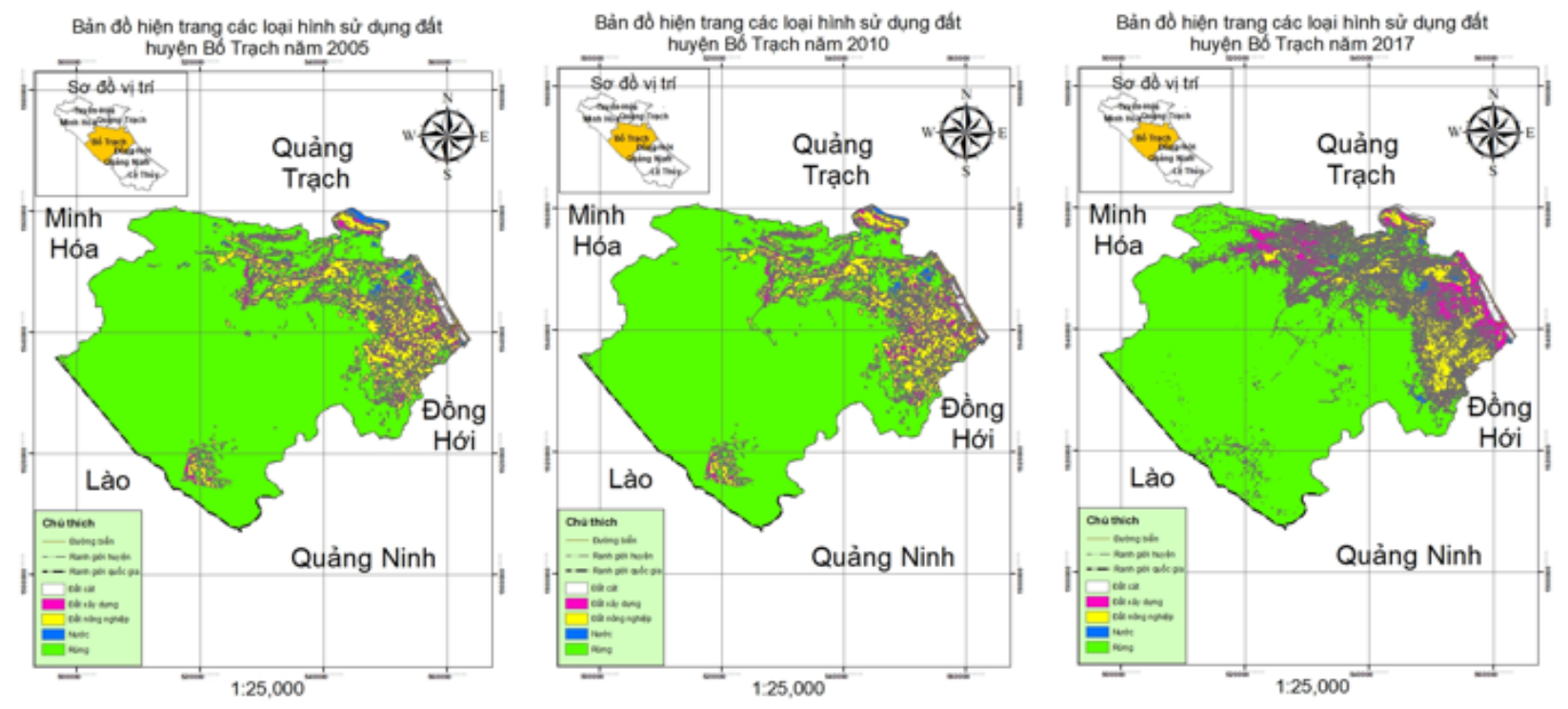

Figure 8. Land cover map in the year 2005, 2010 and 2017

\subsection{Land cover change at Bo Trach district}

\subsubsection{Land cover change 2005-2010}

Land cover change at Bo Trach district during the period 2005-2010 was conducted from overlaid maps. It showed that the total natural area was $212,417.6$ ha and the area of land cover types within Bo Trach district changed differently (Table 3).

- The area of the sandy land retained 2792.6ha (accounting for $90.1 \%$ of its area). In which, sandy land mainly converted 113.7ha (accounting for 3.67\%) to agriculture and 114.6ha (accounting for 3.7\%) to forest. The small rest of sandy land shifted to built-up land with an area of 43.5ha (accounting for $1.4 \%$ ), and to water with an area of 4.2 ha (accounting only $0.13 \%$ ).

- Water retained 2819.7ha (accounting for $75.4 \%$ of its area), $24.6 \%$ of its area changed to other land types. In which, there was 385.7 ha (accounting for $10.31 \%$ ), converting to agricultural land; 342.5ha (accounting for $9.15 \%$ ), converting to forest land; 190.3 ha (accounting for $5.1 \%$ ), converting to built-up land; and 2.9 ha (accounting for $0.08 \%$ ) converting to sandy land. 
- Agricultural retained 20423.1ha (accounting for 96.3\% of its area), only $3.7 \%$ of its area changed to other land types. In which, there was 561.3 ha (accounting for 2.64\%), converting to built-up land; 244.2 ha (accounting for $1.44 \%$ ), converting to forest; and 10.5 ha (accounting for $0.05 \%$ ) converting to sandy land.

- Built-up land retained 10526.4ha (accounting for $96.6 \%$ of its area), only $3.4 \%$ of its area changed to other land types. In which, there was 306.8ha (accounting for $2.81 \%$ ) converting to forest; 42.6ha (accounting for $0.39 \%$ ) converting to water, and 21.7 ha (accounting for $0.2 \%$ ) converting to sand land.

- Forest retained 171287.4 ha (accounting for $98.7 \%$ of its area), only $1.3 \%$ of its area changed to other land types. In which, there was 1956.4ha (accounting for $1.13 \%$ ) converting to agriculture; 134.2ha (accounting for $0.07 \%$ ) converting to built-up land; 33.2ha (accounting for $0.02 \%$ ) converting to water, and 30.1 ha (accounting for $0.01 \%$ ) converting to sandy land.

The result in Table 4 showed that agriculture area increased the most with an area of 1639.8 ha (accounting for $7.7 \%$ of the net increase), and followed by built-up land with the rise in an area of 558.2ha (accounting for $5.1 \%$ of the net increase). Whereas, water area decreased the most with an area of 841.4 ha (accounting for $22.5 \%$ of the net decrease). Sandy land and forest had the reduction of an area of 240.8 ha (accounting for $7.8 \%$ of the net decrease), and 1115.8 ha (accounting for $0.6 \%$ of the net decrease), respectively. As can be seen from analytical data, forest within Bo Trach district was preserved in good condition during the period 2005-2010.

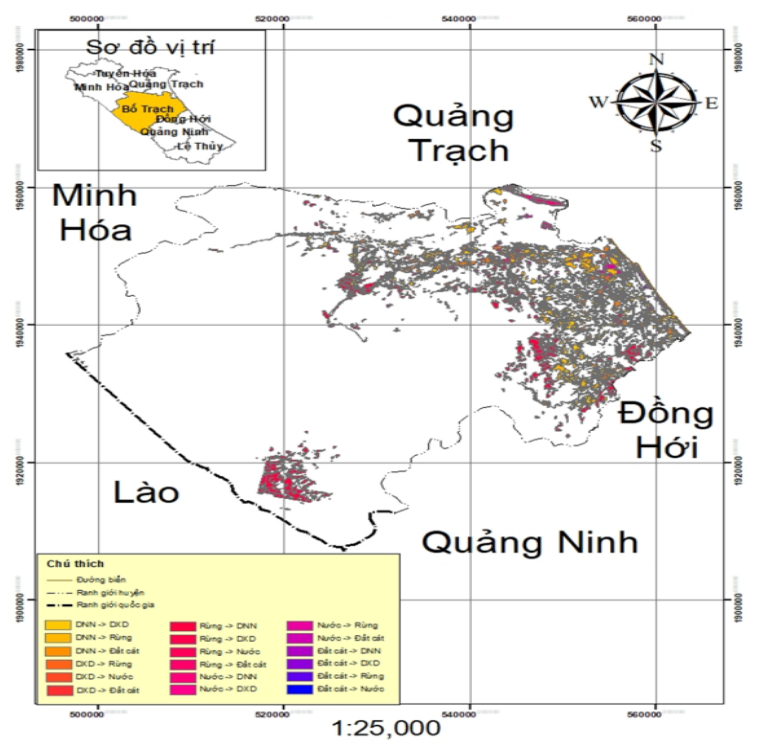

Figure 9. Land cover change map from 2005 to 2010

Table 3. Land cover change in Bo Trach district from 2005 to 2010

Type of land cover Year 2010

\begin{tabular}{lllllll}
\hline Year 2005 & Sandy land & Water & Agriculture land & Built-up land & Forest & Sum \\
Sandy land & $\mathbf{2 7 9 2 . 6}$ & $\mathbf{4 . 2}$ & 113.7 & 43.5 & 114.6 & 3098.6 \\
Water & 2.9 & $\mathbf{2 8 1 9 . 7}$ & 385.7 & 190.3 & 342.5 & 3741.1 \\
Agriculture land & 10.5 & 0 & $\mathbf{2 0 4 2 3 . 1}$ & 561.3 & 244.2 & 21239.1 \\
Built-up land & 21.7 & 42.6 & 0 & $\mathbf{1 0 5 2 6 . 4}$ & 306.8 & 10897.5 \\
Forest & 30.1 & 33.2 & 1956.4 & 134.2 & $\mathbf{1 7 1 2 8 7 . 4}$ & 173441.3 \\
Sum & 2857.8 & 2899.7 & 22878.9 & 11455.7 & 172325.5 & $\mathbf{2 1 2 4 1 7 . 6}$
\end{tabular}

Table 4. The net change of land cover types in Bo Trach district from 2005 to 2010

\begin{tabular}{lcccc} 
Land cover type & \multirow{2}{*}{$\begin{array}{c}\text { Year 2005 } \\
\text { (ha) }\end{array}$} & $\begin{array}{c}\text { Year 2010 } \\
\text { (ha) }\end{array}$ & $\begin{array}{c}\text { Area } \\
\text { (ha) }\end{array}$ & $\begin{array}{c}\text { Percentage } \\
\text { (\%) }\end{array}$ \\
\hline Sandy land & 3098.6 & 2857.8 & -240.8 & -7.8 \\
Water & 3741.1 & 2899.7 & -841.4 & -22.5 \\
Agriculture land & 21239.1 & 22878.9 & 1639.8 & 7.7 \\
Built-up land & 10897.5 & 11455.7 & 558.2 & 5.1 \\
Forest & 173441 & 172325.5 & -1115.8 & -0.6
\end{tabular}

\subsubsection{Land cover change 2010-2017}

Land cover change at Bo Trach district during the period 2105-2017 was conducted from overlaid maps. It showed that the total natural area was still $212,417.6$ ha and the area of land cover types within Bo Trach district changed differently (Table 5).

- The area of the sandy land retained 2637.5ha (accounting for $92.3 \%$ of its area). In which, sandy land mainly converted 127.7 ha (accounting for $4.5 \%$ ) to agriculture and 48.3 ha (accounting for $1.7 \%$ ) to forest. The small rest of sandy land shifted to built-up land with an area of 22.8ha (accounting for $0.8 \%$ ), and to water with an area of 21.5 ha (accounting only $0.74 \%$ ).

- Water retained 2545.7ha (accounting for $87.8 \%$ of its area), $12.2 \%$ of its area changed to other land types. In which, there was 145.5 ha (accounting for 5.01\%), converting to agricultural land; 103.6ha (accounting for $3.57 \%$ ), converting to forest land; 102.3 ha (accounting for $3.53 \%$ ), converting to built-up land; and 2.6ha (accounting for $0.08 \%$ ) converting to sandy land. 


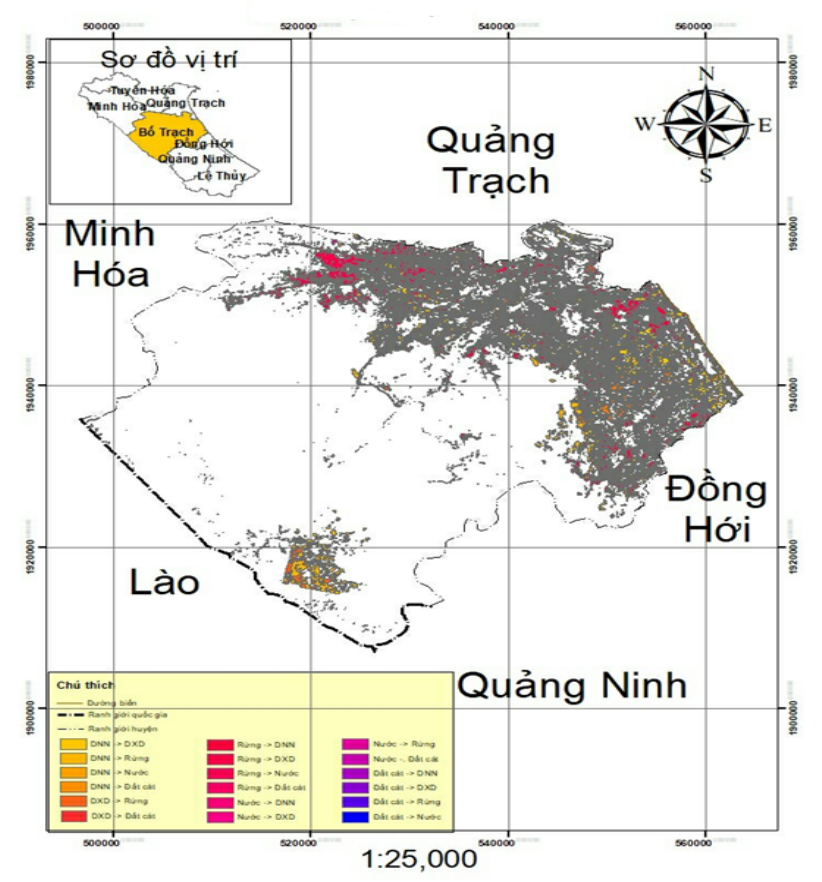

Figure 10. Land cover change map from 2010 to 2017

- Agricultural retained 22725.5ha (accounting for 99.3\% of its area), only $0.7 \%$ of its area changed to other land types. In which, there was 106.4ha (accounting for $0.46 \%$ ), converting to water; 28.5 ha (accounting for $0.12 \%$ ), converting to forest; and 13.2 ha (accounting for $0.06 \%$ ), converting to built-up land; 5.3 ha (accounting for $0.026 \%$ ), converting to sandy land.
- Built-up land retained 11261.2ha (accounting for 98.3\% of its area), only $2.7 \%$ of its area changed to other land types. In which, there was 126.8 ha (accounting for $1.1 \%$ ) converting to forest; 67.7 ha (accounting for $0.67 \%$ ) converting to water.

- Forest retained 169438.7ha (accounting for 98.3\% of its area), only $1.7 \%$ of its area changed to other land types. In which, there was 2157.4 ha (accounting for $1.25 \%$ ) converting to agriculture; 623.1 ha (accounting for $0.07 \%$ ) converting to built-up land; 33.2ha (accounting for $0.36 \%$ ) converting to water, and 106.3ha (accounting for $0.06 \%$ ) converting to sandy land.

The result in Table 6 showed that agriculture area still increased with an area of 2277.2 ha (accounting for $9.95 \%$ of the net increase), and followed by water, rising with an area of 397 ha (accounting for $13.7 \%$ of the net increase). Built-up land increased slightly with an area of 50.1 ha (accounting for $0.44 \%$ of the net increase). Whereas, forest with the decrease the most with an area of 2579.6 ha (accounting for $1.5 \%$ of the net decrease), and follow by sandy land area, decreasing with an area of 144.7ha (accounting for $5.06 \%$ of the net decrease), respectively. The analytical result reflects the region's economic development orientation, which focuses on agriculture concerning the livelihood of the local people. Therefore, land cover planning has been established regarding effective and economic terms of land resources.

Table 5. Land cover change in Bo Trach district from 2010 to 2017

Type of land cover Year 2017

\begin{tabular}{lllllll}
\hline Year 2010 & Sandy land & Water & Agriculture land & Built-up land & Forest & Sum \\
Sandy land & $\mathbf{2 6 3 7 . 5}$ & 21.5 & 127.7 & 22.8 & 48.3 & 2887.8 \\
Water & 2.6 & $\mathbf{2 5 4 5 . 7}$ & 145.5 & 102.3 & 103.6 & 2899.7 \\
Agriculture land & 5.3 & 106.4 & $\mathbf{2 2 7 2 5 . 5}$ & 13.2 & 28.5 & 22878.9 \\
Built-up land & 67.7 & 0 & 0 & $\mathbf{1 1 2 6 1 . 2}$ & 126.8 & 11455.7 \\
Forest & 0 & 623.1 & 2157.4 & 106.3 & $\mathbf{1 6 9 4 3 8 . 7}$ & 172325.5 \\
Sum & 2713.1 & 3296.7 & 25156.1 & 11505.8 & 169745.9 & 212417.6
\end{tabular}

Table 6. The net change of land cover types in Bo Trach district from 2010 to 2017

\begin{tabular}{|c|c|c|c|c|}
\hline \multirow[b]{2}{*}{ Land cover type } & \multirow[b]{2}{*}{$\begin{array}{c}\text { Year } 2005 \\
\text { (ha) }\end{array}$} & \multirow[b]{2}{*}{$\begin{array}{c}\text { Year } 2010 \\
\text { (ha) }\end{array}$} & \multicolumn{2}{|c|}{ Changes } \\
\hline & & & $\begin{array}{c}\text { Area } \\
\text { (ha) }\end{array}$ & $\begin{array}{c}\text { Percentage } \\
(\%)\end{array}$ \\
\hline Sandy land & 2857.8 & 2713.1 & -144.7 & -5.06 \\
\hline Water & 2899.7 & 3296.7 & 397 & 13.7 \\
\hline Agriculture & 22878.9 & 25156.1 & 2277.2 & 9.95 \\
\hline Built-up land & 11455.7 & 11505.8 & 50.1 & 0.44 \\
\hline Forest & 172325.5 & 169745.9 & - & -1.5 \\
\hline
\end{tabular}

\section{Conclusions}

- The steady development of high-resolution satellite imagery, contained substantial information, facilitates the application of remote sensing technology to build thematic maps with high accuracy. Interpreting satellite image by object-oriented approaches have opened up a positive application of remote sensing technology to map the land cover by the quantitative algorithm. Each class is categorized by different classification algorithms which use the individual information of each image channels. From this point of view, the results of remote sensing using objectoriented method are more accurate than the pixel classification perspective. The data allowed studies in land cover map of district level.

- The land cover map in the year of 2005, 2010, and 2017 was created with high accuracy $92.22 \%, 91.28 \%, 94.22 \%$, respectively. The land cover change maps of two periods 2005-2010 (phase 1) and 2010-2017 (phase 2) show that there is a variation in the area of land cover types, especially agriculture and forest land. Of which, agrarian land increased by $7.7 \%$ in period 1 and $9.95 \%$ in period 2 . Whereas, forest land decreased by $0.6 \%$ in period 1 and $1.5 \%$ in period 2 .

Object-oriented approach showed new technique to classification satellite images. Object-oriented classification 
takes time to determine fragmentation parameters and "rule set" to construct the best image interpretation key as well. The required number of samples must be large enough for each class. If the sample size is not sufficient, the threshold range for classification will get errors. It has some advantages in the agriculture area, man-made area, large objects. It also has disadvantages as the common methods (cloud area, spotted objects distribution...).

\section{References}

[1] Forest Inventory and Planning Institute - FIPI (2009), National Forest Inventory Project phase 2010 - 2015.

[2] Ministry of Agriculture and Rural Development MARD (2012), National forest inventory guide for the period $2012-2015$.

[3] Ministry of Agriculture and Rural Development MARD (2012), Decision No.3183/QD-BNN-TCLN date $21 / 12 / 2012$.

[4] Pham Quoc Trung, Nguyen Hoang Khanh Linh, Huynh Van Chuong, Dinh Vu Long (2018), Detecting the change of land cover by remote sensing technology at Bo Trach district, Quang Binh province, Ecological Economy Journal, 55, 31-36.

[5] Trimble eCognition (2015), eCognition Developer Fundamentals Training Overview Version 9.1, accessed on $15 / 03 / 2018$

http://www.ecognition.com/sites/default/files/Learn More_\%20eCognitionFundamentals_030615.pdf. 